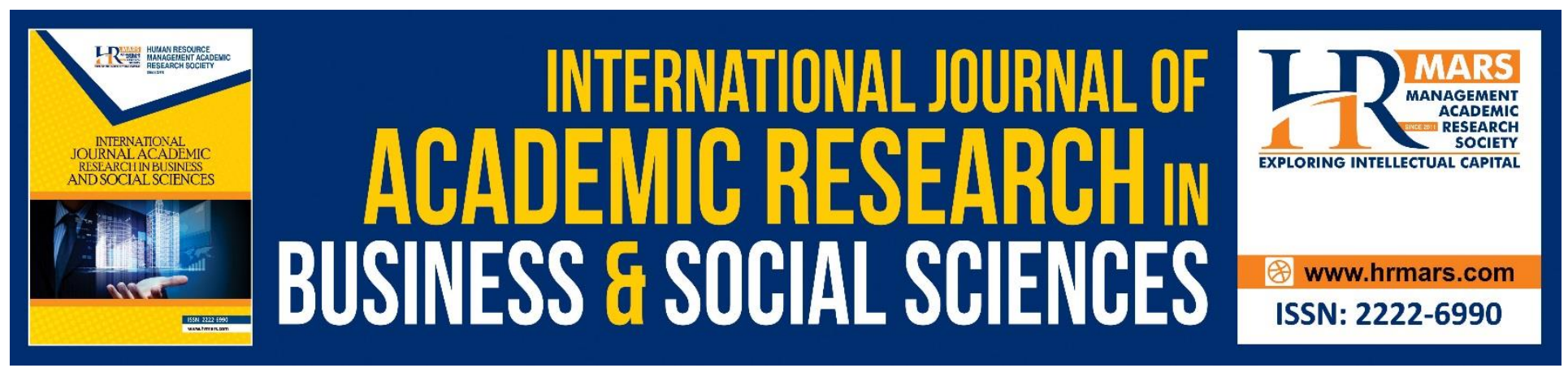

\title{
The Role of Effective Work Force Planning on Managing Government Projects in Enugu State
}

\author{
Nneka, Esther Maduagwu \\ Okonkwo, Adonai Okechukwu Prince \\ Monanu, Oge G.
}

To Link this Article: http://dx.doi.org/10.6007/IJARBSS/v9-i3/5677

DOI: $\quad 10.6007 /$ IJARBSS/v9-i3/5677

Received: 18 Feb 2019, Revised: 14 March 2019, Accepted: 30 March 2019

Published Online: 03 April 2019

In-Text Citation: (Nneka, Okonkwo, \& Monanu, 2019)

To Cite this Article: Nneka, E. M., Okonkwo, A. O. P., \& Monanu, O. G. (2019). The Role of Effective Work Force Planning on Managing Government Projects in Enugu State. International Journal of Academic Research in Business and Social Sciences, 9(3), 278-295.

Copyright: (C) 2019 The Author(s)

Published by Human Resource Management Academic Research Society (www.hrmars.com)

This article is published under the Creative Commons Attribution (CC BY 4.0) license. Anyone may reproduce, distribute, translate and create derivative works of this article (for both commercial and non-commercial purposes), subject to full attribution to the original publication and authors. The full terms of this license may be seen

at: http://creativecommons.org/licences/by/4.0/legalcode

Vol. 9, No. 3, 2019, Pg. 278 - 295

http://hrmars.com/index.php/pages/detail/IJARBSS

JOURNAL HOMEPAGE

Full Terms \& Conditions of access and use can be found at http://hrmars.com/index.php/pages/detail/publication-ethics 


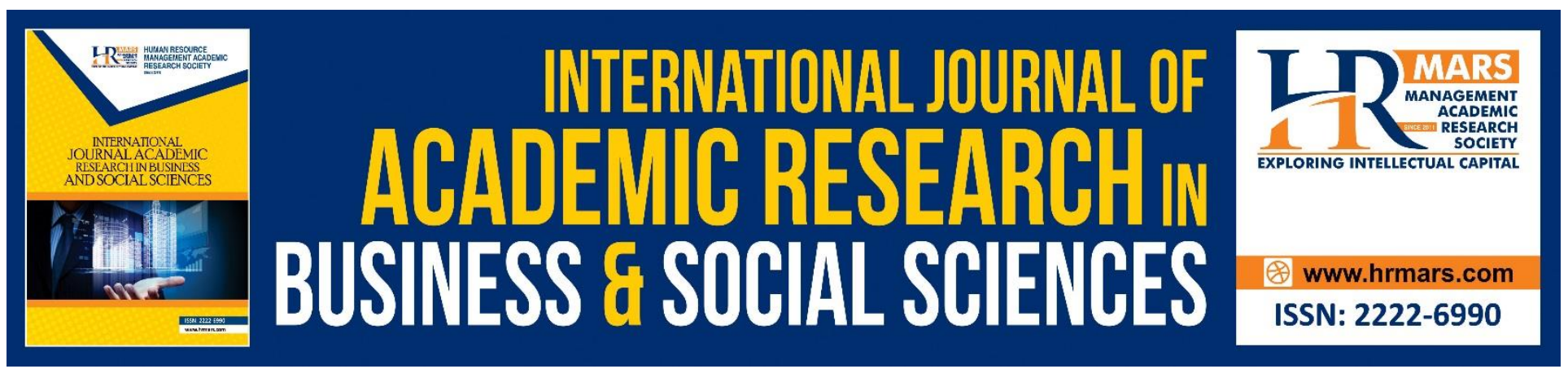

\title{
The Role of Effective Work Force Planning on Managing Government Projects in Enugu State
}

\author{
NNEKA, Esther Maduagwu (Ph.D) \\ Department of Business Administration, Faculty of Management Sciences, \\ Enugu State University of Science and Technology (ESUT), Enugu, Enugu State, Nigeria \\ OKONKWO, Adonai Okechukwu Prince (Ph.D) \\ Department of Business Administration, Faculty of Management Sciences, \\ Enugu State University of Science and Technology (ESUT), Enugu, Enugu State, Nigeria \\ Email: Princenile62@yahoo.com \\ MONANU, Oge G. (Ph.D) \\ Department of Business Administration, Faculty of Management Sciences, \\ Enugu State University of Science and Technology (ESUT), Enugu, Enugu State, Nigeria
}

\begin{abstract}
This study was on the effect of work force planning on management of government projects in Enugu State. The specific objectives were: to ascertain the relationship between effective recruitment and selection plan and Enugu State government projects planning, to determine the effect of talent management plans on Enugu State government projects execution, to ascertain the extent to which effective training and development plans will contribute to Enugu State government projects control and evaluation. The data for this study were collected from two major sources; primary and secondary sources. The entire population of the study was used as the sample size. The research instruments used were structured questionnaire and oral interview schedule. The validity of the research instrument was tested using content analysis while the reliability of the research instrument was tested using test re test method. The result of the test gave a reliability co-efficient of 0.87 which was good. Data for the work was presented using simple table and analysis was done using simple percentages. The three hypotheses were tested using chi-square. The findings showed that there is a positive relationship between effective recruitment/selection plan and project planning in Enugu State government projects, $X^{2}(4, n=40)=64.255, P=0.05$, that talent management plans to a large extent affects project executions in Enugu State government projects, $X^{2}(4, n=40)=31.75, P=0.05$, that effective training and Development plans contribute positively to effective project control and evaluation in Enugu State government projects, $X^{2}(4, n=40)=50, P=0.05$. The study concludes that
\end{abstract}


INTERNATIONAL JOURNAL OF ACADEMIC RESEARCH IN BUSINESS AND SOCIAL SCIENCES

Vol. 9, No. 3, March, 2019, E-ISSN: 2222-6990 @ 2019 HRMARS

workforce planning provides the basis for a systematic approach to assessing the number and type of people needed by an organization and ensuring that people considerations are taken into account in business plans. It recommends among others that Government of Enugu State should ensure that recruitment and selection plan should be made part of the government policy as this will have positive effect on its project planning.

Keywords: Workforce Planning, Project Management

\section{Introduction}

Work force planning is a core process of human resource management that is shaped by the organizational strategy and ensures the right number of people with the right skills, in the right place at the right time to deliver short and long-term organizational objectives (Armstrong, 2012). Human resources are the people an organization employs to carryout various jobs, tasks, and functions in exchange for wages, salaries and other rewards. Organizations whether small or large strive to achieve their set goals by combining various resources into goods and services that will be of value to their customers. Many different resources are available for actual creation of goods and services such as financial resources, human resource, material resource and knowledge based resources. Denisis and Griffin (2005) opine that most (but not all) of the critical knowledge tends to reside in the people in the organization hence managers have come to recognize that no set of resources is more vital to an organization success than its human resources. Therefore to ensure that the right number of people with the right skills and abilities are hired, there is need for effective work force planning. Workforce planning is an integral part of business planning. According to Armstrong (2012), the strategic planning process defines projected changes in the type of activities carried out by the organization and the scale of those activities. It identifies the core competencies the organization needs to achieve its goals and therefore its skills and behavioural requirements.

According to Armstrong, workforce planning interprets these plans in terms of people requirement. He is of the view that it may influence the business strategy by drawing attention to ways in which people could be developed and deployed more effectively to further the achievement of business goals as well as focusing on any problems that might have to be resolved to ensure that the people required will be available and will be capable of making the necessary contribution. Project is a temporary endeavour undertaken to create a unique product or service. Harrison (1992) opines that a project can be considered to be any series of activities and tasks that: Have a specific objective to be completed within certain specifications, have defined start and date and ave funding limits Consume resources.

Project management is the achievement of a project's objectives through people and involves the organizing, planning and control of the resources assigned to the project together with the development of constructive human relations with all those involved, both in company and with the other companies involved (Harrison, 1992). From the above assertions one can understand that project execution entails utilization of resources (finance, materials, technology, knowledge and people) and among all these resources, human resources is the core among them. Therefore to ensure that the objective of the project is achieved at the right time and with the effective utilization of other resources, there is need for the right personnel's to execute the job to be in place in the right number and with the required skills and abilities hence the need for effective human resource 
planning. Some project managers have ignored this important aspect of their responsibilities hence resulting to project failures. Therefore, this work is aimed at determining the role of effective work force planning on managing government projects in Enugu State.

\section{Statement of Problem}

Project and project management are taking increasing important roles in industry, commence, public sector organizations and at every level of government. This is because the rate of change facing industry is on increase due to global forces. Some managers or chief executives fail to understand that management of projects is different from the management of its other operations and this affects their decision making towards the project negatively. The resultant effects of these are inappropriate planning to the scope of the project, failure in many organizations to produce accurate forecasts and therefore prepare meaningful plans that led to accurate recruitment and selection of project members and project teams, in-effective talent management, lack of effective employee training and development, poor project design, ineffective managing and controlling project resources. These are some of the reasons why a lot of projects are abandoned. Some of the projects are delayed and delivered at a very high cost. Some project managers also deliver poor quality projects just because they fail to do the needful at the right time. Therefore, this work is necessitated to determine how effective work force planning can serve as a tool for effective and efficient management of Enugu State government projects.

\section{Research Objectives}

The main thrust of the study was to determining how effective work force planning can serve as a tool for Enugu State government projects management. The specific objectives were:

1. To ascertain the relationship between effective recruitment and selection plan and Enugu State government projects planning.

2. To determine the effect of talent management plans on Enugu State government projects execution.

3. To ascertain the extent to which effective training and development plans will contribute to Enugu State government projects control and evaluation.

\section{Research Questions}

1. What is the nature of relationship between effective recruitment and selection plan and Enugu State government projects planning?

2. What is the effect of talent management plans on Enugu State government projects execution?

3. To what extent does an effective training and development plan contribute to Enugu State government projects control and evaluation?

\section{Research Hypotheses}

$\mathrm{H} 1$ : There is significant relationship between effective recruitment and selection plans and Enugu State government projects planning. 
INTERNATIONAL JOURNAL OF ACADEMIC RESEARCH IN BUSINESS AND SOCIAL SCIENCES

Vol. 9, No. 3, March, 2019, E-ISSN: 222 2-6990 C 2019 HRMARS

$\mathrm{H} 2$ : Talent management plans to a large extent affect Enugu State government projects execution?

H3: Effective Training and Development plans to a large extent contribute to Enugu State

government projects control and evaluation.

\section{Conceptual Frame Work of the study \\ Concept of Work Force Planning}

CIPD (2010a: 4) defines 'Workforce planning as a core process of human resource management that is shaped by the organizational strategy and ensures the right number of people with the right skills, in the right place at the right time to deliver short and long-term organizational objectives.' Workforce planning may be conducted as an overall approach to establishing and satisfying people requirements covering all major employee categories and skills (Armstrong, 2012).

Rothwell (1995) distinguished between HR planning in the hard sense; 'this serves as an indicator of the likely match or mismatch of the supply and demand for the right number of people with appropriate skills' and HR planning in the soft sense; which serve 'to alert the organization to the implications of business strategy for people development, culture and attitudes as well as numbers and skills'. The CIPD (2010a) made a similar distinction between 'hard' and 'soft' workforce planning. They opine that hard workforce planning is about numbers which often revolved around using past trends to predict the future, matching supply and demand for labour with the result that plans were often out of date before the ink was dry. Soft workplace planning focuses on general issues relating to the supply of and demand for people and how they are deployed.

\section{The link between workforce and business planning}

Workforce planning is an integral part of business planning. The strategic planning process defines projected changes in the types of activities carried out by the organization and the scale of those activities. It identifies the core competencies the organization needs to achieve its goals and therefore its skill and behavioural requirements.

Workforce planning interprets these plans in terms of people requirements. But it may influence the business strategy by drawing attention to ways in which people could be developed and deployed more effectively to further the achievement of business goals as well as focusing on any problems that might have to be resolved to ensure that the people required will be available and will be capable of making the necessary contribution (Armstrong, 2012).

\section{The rationale for workforce planning}

Workforce planning provides the basis for a systematic approach to assessing the number and type of people needed by an organization and ensuring that people considerations are taken into account in business plans. Having obtained information on the supply of people, and from environmental scanning, it leads to the preparation of recruitment, retention, management succession and talent management plans. It is important because it encourages employers to develop clear and explicit links between their business and HR plans and to integrate the two more effectively. It allows for better control over staffing costs and numbers employed, and it enables employers to make more informed judgments about the skills mix in their organizations. 
The four key steps of HRP process are:

\section{(a) Analyzing present labour supply:}

The first step of HRP is to identify the company's strengths and weakness in the current labour pool. The company will perform a comprehensive audit of the skills, demographic, qualifications, experience and compensation of every worker. HR managers will determine if the organization need to hire more staff to compete in a future market place or are more automated tools necessary to capture more market share from competitors.

\section{(b) Forecasting Demand:-}

HR forecasts demand based on strategic goals of the company. HR manager may examine the market trends, industry analysis and technological improvements to try to come up with ways to meet the company's goals.

Do retired employees need to be replaced or can new technology do the job? Does the company need more full-time workers, part-time help or outsourced labour?

\section{(c) Striking a Balance:}

Striking a balance between supply and demand. At this point, HR creates a gap analysis that lay out specific need to narrow the supply of the company's labour versus future demand. Should employees learn new skills in the future? Does the company need more managers? Do all employees play to their strengths in their current roles?

\section{(d) Integrating the plan:}

This is the final phase of the HRP process. HR must now take practical steps to integrate its plan with the rest of the company. The overall goal of HR planning is to have the optimal amount of staff to make the most money for the company. HR planning is a regular occurrence because the goals and strategies of the company change over time.

\section{Concept of Project}

A project is a temporary endeavor undertaken to create a unique product, service or result. A project is temporary in that it has a defined beginning and end in time, and therefore defined scope and resources. And a project is unique in that it is not a routine operation, but a specific set of operations designed to accomplish a singular goal. So a project team often includes people who don't usually work together - sometimes from different organizations and across multiple geographies. Examples of projects include the development of software for an improved business process, the construction of a building or bridge, the relief effort after a natural disaster, the expansion of sales into a new geographic market. The temporary nature of projects stands in contrast with business as usual (or operations) which are repetitive, permanent, or semi-permanent functional activities to produce products or services (Paul, et al 2005). In practice, the management of such distinct production approaches requires the development of distinct technical skills and management strategies (Cattani, et al 2011). Hence projects must be expertly managed in order to be delivered on-time, on specified budget, outcome and integration that organizations need. 


\section{Concept of Project Management}

Project management is the application of knowledge, skills, tools, and techniques to project activities to meet the project requirements. Joseph, (2003) opines that project management is the practice of initiating, planning, executing, controlling, and closing the work of a team to achieve specific goals and meet specific success criteria at the specified time. He stated that the primary challenge of project management is to achieve all of the project goals within the given constraints. This information is usually described in project documentation, created at the beginning of the development process. The primary constraints are scope, time, quality and budget (PMI, 2010). The secondary and more ambitious challenge is to optimize the allocation of necessary inputs and apply them to meet pre-defined objectives. The object of project management is to produce a complete project which complies with the client's objectives. In many cases the object of project management is also to shape or reform the client's brief in order to feasibly be able to address the client's objectives. Once the client's objectives are clearly established they should impact on all decisions made by other people involved in the project - project managers, designers, contractors, subcontractors, etc. If the project management objectives are ill-defined or too tightly prescribed it will have detrimental effect on decision making. (Mesly, 2017) therefore suggests that the success of any project depends on how well

four key aspects are aligned with the contextual dynamics affecting the project; these are referred to as the four P's

- Plan: The planning and forecasting activities.

- Process: the overall approach to all activities and project governance.

- People: and the dynamics of how they collaborate and communicate.

- Power: Projects should describe all lines of authority, decision-makers, organ grams, policies for implementation and the likes.

Mesly, (2017) opines that the major five project management process groups generally include;

- Initiation

- Planning

- Production or execution

- Monitoring and controlling

- Closing

1. Initiating

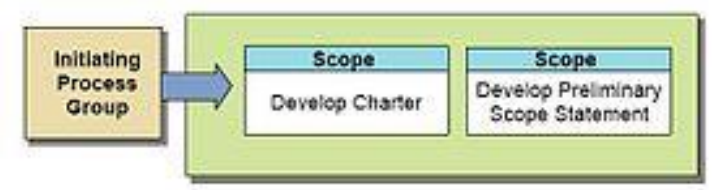

Fig 1.Initiating process group processes-as adapted from Peter and Jones (2003). PMP certification for dummies. p.63. The initiating processes determine the nature and scope of the project Abdou, Saed, Yong, Kuan, Othman and Mohammed (2016). If this stage is not performed well, it is unlikely that the project will be successful in meeting the business' needs. The key project controls needed here are an understanding of the business environment and making sure that all necessary controls are incorporated into the project. Any deficiencies should be reported and a recommendation should be 
made to fix them. The initiating stage should include a plan that encompasses the following areas. These areas can be recorded in a series of documents called Project Initiation documents. Project Initiation documents are a series of planned documents used to create order for the duration of the project. These tend to include:

- $\quad$ project proposal (idea behind project, overall goal, duration)

- $\quad$ project scope (project direction and track)

- $\quad$ product breakdown structure (PBS) (a hierarchy of deliverables / outcomes and components thereof)

- $\quad$ work breakdown structure (WBS) (a hierarchy of the work to be done, down to daily tasks)

- responsibility assignment matrix (RACI) (roles and responsibilities aligned to deliverables / outcomes)

- tentative project schedule (milestones, important dates, deadlines)

- analysis of business needs and requirements against measurable goals

- review of the current operations

- financial analysis of the costs and benefits, including a budget

- stakeholder analysis, including users and support personnel for the project

- $\quad$ project charter including costs, tasks, deliverables, and schedules

- SWOT analysis: strengths, weaknesses, opportunities, and threats to the business

\section{Planning}

After the initiation stage, the project is planned to an appropriate level of detail as seen in fig. 1 . The main purpose is to plan time, cost and resources adequately to estimate the work needed and to effectively manage risk during project execution. As with the Initiation process group, a failure to adequately plan greatly reduces the project's chances of successfully accomplishing its goals.

Lewis, (2000) opines that Project planning generally consists of;

- determining the project management methodology to follow (e.g. whether the plan will be defined wholly up front, iteratively, or in rolling waves);

- developing the scope statement;

- selecting the planning team;

- identifying deliverables and creating the product and work breakdown structures;

- identifying the activities needed to complete those deliverables and networking the activities in their logical sequence;

- estimating the resource requirements for the activities;

- estimating time and cost for activities;

- developing the schedule;

- developing the budget;

- risk planning;

- developing quality assurance measures;

- gaining formal approval to begin work.

Additional processes, such as planning for communications and for scope management, identifying roles and responsibilities, determining what to purchase for the project and holding a kick-off meeting are also generally advisable. 


\section{Executing}

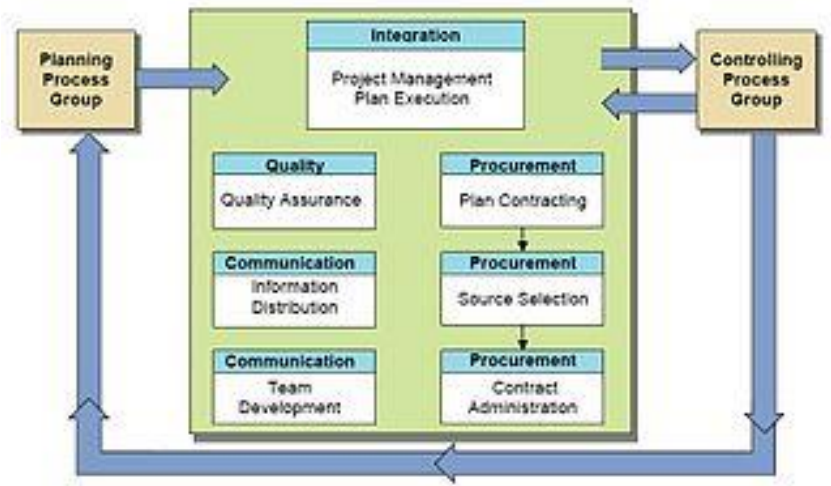

Fig. 2 Executing process group processes as adapted from Peter and Jones (2003). PMP certification for dummies. p.63

While executing the project manager must know what are the planned terms that need to be executed. The execution/implementation phase ensures that the project management plan's deliverables are executed accordingly. This phase involves proper allocation, co-ordination and management of human resources and any other resources such as material and budgets. The output of this phase is the project deliverables.

\section{Project Documentation}

Documenting everything within a project is key to being successful. In order to maintain budget, scope, effectiveness and pace a project must have physical documents pertaining to each specific task. With correct documentation, it is easy to see whether or not a project's requirement has been met. To go along with that, documentation provides information regarding what has already been completed for that project. Documentation throughout a project provides a paper trail for anyone who needs to go back and reference the work in the past. In most cases, documentation is the most successful way to monitor and control the specific phases of a project. With the correct documentation, a project's success can be tracked and observed as the project goes on. If performed correctly documentation can be the backbone to a project's success.

\section{Monitoring and controlling}

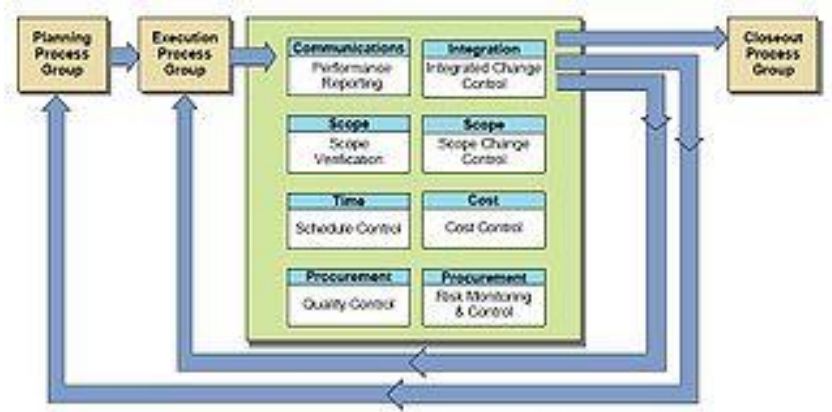

Monitoring and controlling process group processes-as adapted from Peter and Jones (2003). PMP certification for dummies. p.63. Monitoring and controlling consists of those processes performed to observe project execution so that potential problems can be identified in a timely manner and corrective action can be taken, when necessary, to control the execution of the project. The key 
benefit is that project performance is observed and measured regularly to identify variances from the project management plan. Monitoring and controlling according to "Project Management planning activities Guide"(2013) includes:

- Measuring the ongoing project activities ('where we are');

- Monitoring the project variables (cost, effort, scope, etc.) against the project management plan and the project performance baseline (where we should be);

- Identifying corrective actions to address issues and risks properly (How can we get on track again);

- Influencing the factors that could circumvent integrated change control so only approved changes are implemented.

In multi-phase projects, the monitoring and control process also provides feedback between project phases, in order to implement corrective or preventive actions to bring the project into compliance with the project management plan.

PMI (2010) states that Project maintenance is an ongoing process, and it includes:

- Continuing support of end-users

- Correction of errors

- Updates to the product over time

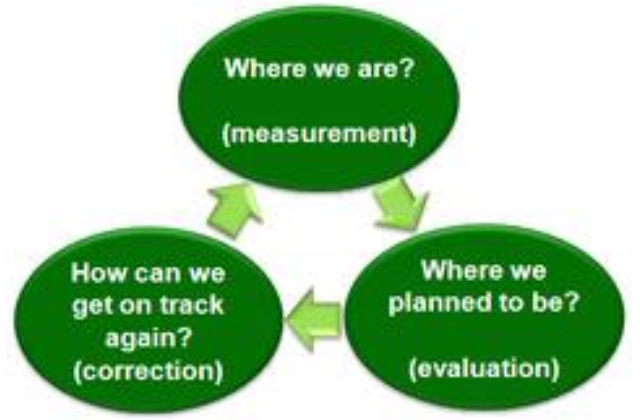

Monitoring and controlling cycle as adapted from Peter and Jones (2003). PMP certification for dummies. p.63

Recruitment and selection: Recruitment is the process of gathering qualified applicants for available positions within an organization (Mathis and Jackson, 2004), and deciding whether to employ the qualified applicants or to reject them. Selection involves choosing the most suitable applicants who satisfy the requirements for a particular job. The practice of selection is a decision-making activity or a psychological calculation of appropriateness. 


\section{Talent Management}

DDI (2018) defines talent management as a mission critical process that ensures organizations have the quantity and quality of people in place to meet their current and future business priorities. Careful planning, culminating in a sound talent strategy that is tightly connected to the organization's overall business strategies and business needs, is required for talent management to become ingrained in an organization's culture and practices. The process covers all key aspects of an employee's "life cycle:" selection, development, succession and performance management. Talent management is also an organization's commitment to recruit, hire, retain, and develop the most talented and superior employees available in the job market.

Organizations know that they must have the best talent in order to succeed in the hyper-competitive and increasingly complex global economy. Along with the understanding of the need to hire, develop, and retain talented people, organizations are aware that they must manage talent as a critical resource to achieve the best possible results. This is because replicating a high-quality, highly engaged workforce is nearly impossible. Also the ability to effectively hire, retain, deploy, and engage talentat all levels -is really the only true competitive advantage an organization possesses.

\section{Employee Training and Development}

Training is a program that helps employees learn specific knowledge or skills to improve performance in their current roles. Development is more expansive and focuses on employee growth and future performance, rather than an immediate job role. Training and development is an important element of HRM (Vlachos, 2009). Training is a marshaled activity that aims to impart instructions or information to improve the performance, knowledge, or skills of the trainee (Saed \& Asgher, 2012). Development refers to the activities that help individuals attain new knowledge or skills that are necessary for their personal growth. Apospori, Nikandrou, Brewster, and Papalexandris (2008) found that training has a significant effect on organizational performance. Subramaniam et al. (2011) argued that training and development could influence the performance of an organization because the skills, knowledge, and abilities of employees could be improved continuously. AL-Qudah, Osman, Ab Halim, and Al-Shatanawi (2014) stated that a significant relationship exists between training and development and organizational performance. Blair (2007) found that investment on training and development could produce huge benefits for an organization. Among them are; greater productivity, employees will feel more engaged and talent can be nurtured and developed.

\section{Theoretical Framework}

\section{Human Capital Theory}

Human capital is a term popularized by Gary Becker, an economist and Nobel Laureate from the University of Chicago, Theodore Schultz, and Jacob Mincer. Human Capital Theory refers to the aggregate stock of competencies, knowledge, social, and personal attributes embodied in the ability to create intrinsic and measurable economic value. Human Capital Theory views humans and individuals as economic units acting as their own economy. The subject is closely associated with the study of human resources management as found in the practice of business administration and macroeconomics. The original idea of human capital can be traced back at least to Adam Smith in the 18th century. The role of human capital is widely discussed in economic development, productivity 
INTERNATIONAL JOURNAL OF ACADEMIC RESEARCH IN BUSINESS AND SOCIAL SCIENCES

Vol. 9, No. 3, March, 2019, E-ISSN: 2222-6990 @ 2019 HRMARS

analysis, innovation, public policy, and education. The basic concept of Human Capital Theory is that investments in individuals can be mathematically measured based on the economic value they are able to contribute to society, hence its relevance to the study.

\section{Empirical Review}

Saifalislam, Osman, and AlQudah, ( 2014) examine the impact of Human Resource Management (HRM) practices as well as the factors that affect recruitment and selection as well as training and development on the organization performance of the Jordanian Public University in the Kingdom of Jordan. The sample comprises staff and lecturers of the university. To achieve the study objectives, the researchers developed a questionnaire, which was administered in a survey. The collected data were analyzed by using SPSS. The analysis of the descriptive statistics and correlations indicated that recruitment and selection as well as training and development significantly correlated with the organizational performance of the Jordanian Public University. The study recommended among others that Human resources, which are considered as the greatest asset of an organization, refer to people whose knowledge, skills, and abilities are utilized to create and to deliver effective services that effective recruitment and selection attracts the right quality and quantity of people, develops the knowledge, skills, and abilities of employees, and retains employees within the organization.

Mohammadnoor Khaled M. AL-Qudah, Abdullah Osman, Mohd Suberi Ab. Halim and Hamza Ali AlShatanawi (2014) examined the effect of human resource (HR) planning, training and development towards organizational performance in the Government Ministry in the Kingdom of Jordan. It investigated the factors that affect HR planning, training and development in Jordanian ministries. The study population, which consisted of employees in the HR departments in 23 Jordanian ministries, comprised 166 respondents. To achieve the study objectives, the researcher developed and distributed a questionnaire, and collected and analyzed the data using SPSS. An overall analysis was performed based on the descriptive statistics and correlation analysis. The results indicated that HR planning, training and development significantly correlated with the organizational performance in the Jordanian Ministry.

\section{METHODOLOGY}

The researcher adapted a descriptive survey design. The government projects studied were Reconstruction of poly clinic-llukwe by BUXTEC Construction Company Limited and Enugu state medical diagnostic centre, GRA Enugu by Anbeez construction Services Limited. The duration of the project was between 2013-2018. The data for this study were collected from two major sources; primary and secondary sources. The major instruments for data collection were questionnaire, interviews, and observations. The population of the study was made up of 5 project managers, 10 supervisors and 25 Foremen of the two companies handling the projects. Therefore the total number of the population of study was forty (40). The entire population of the study was used as the sample size. The content validity of the research instrument was used in this study. The reliability of the instrument was established through test re test method. Data for the work was presented using simple table and analysis was done using simple percentages. Hypothesis as stated in chapter one will be tested using chi-square 
INTERNATIONAL JOURNAL OF ACADEMIC RESEARCH IN BUSINESS AND SOCIAL SCIENCES

Vol. 9, No. 3, March, 2019, E-ISSN: 222 2-6990 ¿ 2019 HRMARS

DATA PRESENTATION

TABLE 4.1: DISTRIBUTION AND RETURN R ate OF QUESTIONNAIRE

\begin{tabular}{|l|c|c|c|}
\hline Categories & $\begin{array}{c}\text { Number } \\
\text { distributed }\end{array}$ & $\begin{array}{c}\text { Number } \\
\text { returned }\end{array}$ & $\begin{array}{c}\text { \% number } \\
\text { returned }\end{array}$ \\
\hline Managers & 5 & 5 & 12.5 \\
\hline Supervisors & 10 & 10 & 25 \\
\hline Foremen & 25 & 25 & 62.5 \\
\hline Total & 40 & 40 & 100 \\
\hline
\end{tabular}

Field Summary, 2018

Table 4.1 shows that $5(12.5 \%)$ questionnaire was distributed to project managers and returned, $10(25 \%)$ questionnaire was distributed to supervisor returned and $25(62.5 \%)$ questionnaire was distributed to the Foremen and returned. This shows a $100 \%$ return rate of the questionnaire distributed.

TABLE 4.2: Research Question I whether there is a relationship between effective recruitment/ selection plan and project planning in Enugu state Government projects.

\begin{tabular}{|l|c|c|c|c|c|}
\hline Options & Managers & Supervisors & Foremen & Frequency & Percentage \\
\hline S. Agree & 5 & 6 & 18 & 29 & 72.5 \\
\hline Agree & - & 2 & 5 & 7 & 17.5 \\
\hline Undecided & - & - & 2 & 2 & 5 \\
\hline Disagree & - & 2 & & 2 & 5 \\
\hline S. disagree & - & $\overline{10}$ & $\overline{25}$ & $\overline{40}$ & $\overline{100}$ \\
\hline Total & 5 & &
\end{tabular}

\section{Field Summary, 2018}

Table 4.1 shows that $36(90 \%)$ of the respondents agreed to the statement while $4(10 \%)$ disagreed to the statement. This shows that there is a strong positive relationship between effective recruitment/ selection plan and project planning.

Table 4.3: Research Question 2: whether talent management plans affects project execution in Enugu state Government projects

\begin{tabular}{|l|c|c|c|c|c|}
\hline Options & Managers & Supervisors & Foremen & Frequency & Percentage \\
\hline S. Agree & 3 & 5 & 12 & 20 & 50 \\
\hline Agree & 2 & 3 & 10 & 15 & 37.5 \\
\hline Undecided & - & - & 3 & 3 & 7.5 \\
\hline Disagree & - & 2 & 2 & 2 & \\
\hline S. disagree & - & $\overline{10}$ & $\overline{25}$ & $\overline{40}$ & 5 \\
\hline Total & 5 & \multicolumn{2}{|c|}{} &
\end{tabular}

Field Summary, 2018 
INTERNATIONAL JOURNAL OF ACADEMIC RESEARCH IN BUSINESS AND SOCIAL SCIENCES

Vol. 9, No. 3, March, 2019, E-ISSN: 222 2-6990 ¿ 2019 HRMARS

Table 4.3 shows that 30 or $(80.5 \%)$ of the respondents agreed that talent management plans will affect project execution while ( 5 or $12.5 \%$ ) of the respondents disagreed to the statement. This shows that talent management plans has a positive effect on project execution.

1. Table 4.4: Research Question 3: Whether training and development plans will contribute to effective project control and evaluation in Enugu State.

\begin{tabular}{|l|c|c|c|c|c|}
\hline Options & Managers & Supervisors & Foremen & Frequency & Percentage \\
\hline S. Agree & 5 & 8 & 13 & 26 & 65 \\
\hline Agree & - & 2 & 18 & 10 & 25 \\
\hline Undecided & - & - & 2 & 2 & 5 \\
\hline Disagree & - & - & - & 2 & 5 \\
\hline S. disagree & - & - & - & $-\overline{40}$ & -100 \\
\hline Total & 5 & 10 & 25 & \\
\hline
\end{tabular}

Field Summary, 2018

Table 4.4 shows that 36 or (90\%) of the respondents agreed that training and development plans will contribute to effective project control and evaluation in Enugu State while 10 or (10\%) of the respondents disagreed to the statement. This shows that training and development plans will contribute positively to effective project control and evaluation in Enugu State

\section{TEST OF HYPOTHESIS}

\section{Hypothesis One}

There is significant relationship between recruitment/selection plan and project planning in Enugu State government projects.

$$
X^{2} \quad=\frac{\Sigma(O-\varepsilon)^{2}}{\varepsilon}
$$

Where: $\quad \mathrm{X}^{2}=$ Chi-square

$$
\begin{array}{lll}
\varepsilon & = & \text { Summation } \\
0 & = & \text { Observed frequency } \\
\Sigma & = & \text { Expected frequency }
\end{array}
$$

\section{Decision Rule}

If calculated value is greater than the tabulated value, then we reject the null hypothesis (Ho) and accept the alternate hypothesis ( $\mathrm{Hi})$

Test at $5 \%$ level of significance, Degree of freedom

$\mathrm{n}-1=5-1=4, \mathrm{X}^{2}$ tabulated 9.488 
INTERNATIONAL JOURNAL OF ACADEMIC RESEARCH IN BUSINESS AND SOCIAL SCIENCES

Vol. 9, No. 3, March, 2019, E-ISSN: 222 2-6990 @ 2019 HRMARS

Table 4.5: Contingency table; Response on table 4.2

\begin{tabular}{|l|c|c|c|c|c|}
\hline Options & 0 & $\Sigma$ & $0-\Sigma$ & $(\mathrm{O}-\mathrm{e})^{2}$ & $(\mathrm{O}-\mathrm{e})^{2} / \Sigma$ \\
\hline S. Agree & 29 & 8 & 21 & 441 & 55.13 \\
\hline Agree & 7 & 8 & -1 & 1 & 0.125 \\
\hline Undecided & 2 & 8 & -6 & 36 & 4.5 \\
\hline Disagree & 2 & 8 & -6 & 36 & 4.5 \\
\hline S. disagree & - & - & & - & - \\
\hline Total & 40 & & & & 64.255 \\
\hline
\end{tabular}

Field Summary, 2018

Table 4.5 shows that the Chi-Square calculated (64.255) is greater than the Chi square tabulated (9.488) at 0.05 level of significance and 4 degree of freedom, we reject null hypothesis and accept alternate hypothesis and conclude that there is a positive significant relationship between recruitment/selection plans and Enugu State government project planning.

\section{Hypothesis Two}

Talent management plans to a large extent affects project execution in Enugu State government project.

Decision Rule: If calculated value is greater than the tabulated value, then we reject the null hypothesis ( $\mathrm{Ho})$ and accept the alternate hypothesis $(\mathrm{Hi})$

Test at $5 \%$ level of significance, Degree of freedom $\mathrm{n}-1=5-1=4, \mathrm{X}^{2}$ tabulated 9.488

Table 4.6: Contingency table, response on table 4.3

\begin{tabular}{|l|c|c|c|c|c|}
\hline Options & $\mathrm{O}$ & $\Sigma$ & $\mathrm{O}-\Sigma$ & $(\mathrm{O}-\mathrm{e})^{2}$ & $(\mathrm{O}-\mathrm{e})^{2} / \Sigma$ \\
\hline S. Agree & 20 & 8 & 12 & 144 & 18 \\
\hline Agree & 15 & 8 & 7 & 49 & 6.125 \\
\hline Undecided & 3 & 8 & -5 & 25 & 3.125 \\
\hline Disagree & 2 & 8 & -6 & 36 & 4.5 \\
\hline S. disagree & - & - & - & - & - \\
\hline Total & 40 & & & & 31.75 \\
\hline
\end{tabular}

Field Summary, 2018

Table 4.6 shows that the Chi-Square calculated (31.75) is greater than the Chi square tabulated (9.488) at 0.05 level of significance and 4 degree of freedom, we reject null hypothesis and accept alternate hypothesis and conclude that talent management plans to a large extent affects Enugu State government project execution.

Hypothesis Three

Training and Development plans to a large extent contribute to effective Enugu State government project control and evaluation. 
Decision Rule: If calculated value is greater than the tabulated value, then we reject the null hypothesis $(\mathrm{Ho})$ and accept the alternate hypothesis $(\mathrm{Hi})$

Test at $5 \%$ level of significance, Degree of freedom $\mathrm{n}-1=5-1=4, \mathrm{X}^{2}$ tabulated 9.488

Table 4.7: Contingency table, response on table 4.3

\begin{tabular}{|l|c|c|c|c|c|}
\hline Options & 0 & $\Sigma$ & $0-\Sigma$ & $(\mathrm{O}-\mathrm{e})^{2}$ & $(\mathrm{O}-\mathrm{e})^{2} / \Sigma$ \\
\hline S. Agree & 26 & 8 & 18 & 324 & 40.5 \\
\hline Agree & 10 & 8 & 2 & 4 & 0.5 \\
\hline Undecided & 2 & 8 & -6 & 36 & 4.5 \\
\hline Disagree & 2 & 8 & -6 & 36 & 4.5 \\
\hline S. disagree & - & - & - & - & - \\
\hline Total & 40 & & & & 50 \\
\hline
\end{tabular}

Field Summary, 2018

Table 4.7 shows that the Chi-Square calculated (50) is greater than the Chi square tabulated (9.488) at 0.05 level of significance and 4 degree of freedom, we reject null hypothesis and accept alternate hypothesis and conclude that Training and development plans contributes positively to effective Enugu state project control and evaluation.

\section{Discussion of Findings \\ Objective I}

The nature of relationship between recruitment/selection plans and Enugu State government projects planning.

The result of the finding shows that the calculated value of the Chi-square is greater than the tabulated Chi-square, $X^{2}$ cal $64.255>X^{2}$ tab. 9.488. Therefore the null hypothesis was rejected and the alternate hypothesis accepted that there is a significant positive relationship between recruitment/selection plans and Enugu State government projects planning. Also According to Mathis and Jackson (2004), Recruitment is the process of gathering qualified applicants for available positions within an organization and deciding whether to employ the qualified applicants or to reject them. Selection involves choosing the most suitable applicants who satisfy the requirements for a particular job.

Objective 2: To determine the effect of talent management plans on Enugu State government projects execution.

In determining the effect of talent management plans on project execution in Enugu State government rejects, the result of the analysis shows that the calculated value of the Chi-square is greater than the tabulated Chi-square; hence $X^{2}$ cal 31.75 $>X^{2}$ tab. 9.488. Therefore the null hypothesis was rejected and the alternate hypothesis accepted that talent management plans to a large extent affects Enugu State government project execution. DDI (2018) supports this finding by defining talent management as a mission critical process that ensures organizations have the quantity and quality of people in place to meet their current and future business priorities. 
Objective 3: To ascertain the extent to which effective training and development plans will contribute to Enugu State government projects control and evaluation.

The result of the third hypothesis shows that effective training and development plans contributes positively to effective project control and evaluation in Enugu State government projects. Hence the null hypothesis was rejected and the alternate hypothesis accepted; as $X^{2}$ cal $50>X^{2}$ tab 9.488. In support of this Blair (2007) found that investment on training and development could produce huge benefits for an organization. Among them are; greater productivity, employees will feel more engaged and talent can be nurtured and developed.

\section{Summary of Findings}

1. There is a positive relationship between effective recruitment/selection plan and Enugu State government project planning. From the tested hypothesis one $X^{2}(4, n=40)=64.255, P=0.05$. Hence alternate hypothesis was accepted.

2. Talent management plans to a large extent affects Enugu State government project executions. From the tested hypothesis two $X^{2}(4, n=40)=31.75, P=0.05$.

3. That effective training and Development plans contribute positively to effective Enugu State government project control and evaluation. From the tested hypothesis three, $X^{2}(4, n=40)$ $=50, P=0.05$.

\section{Conclusion}

Workforce planning provides the basis for a systematic approach to assessing the number and type of people needed by an organization and ensuring that people considerations are taken into account in business plans. Having obtained information on the supply of people, and from environmental scanning, it leads to the preparation of recruitment, retention, management succession and talent management plans. It is important because it encourages employers to develop clear and explicit links between their business and HR plans and to integrate the two more effectively. It allows for better control over staffing costs and numbers employed, and it enables employers to make more informed judgments about the skills mix in their organizations.

\section{Recommendations}

Based on the findings, the following recommendations were made

1. Government of Enugu State should ensure that recruitment and selection plan should be made part of the government policy as this will have positive effect on its project planning.

2. Project managers should have effective talent management plans to ensure employee retention. This will contribute to timely project execution.

3. Government policy statement should also accommodate effective training and development plans for newly employed and those already in the job to acquire better skill and knowledge 
INTERNATIONAL JOURNAL OF ACADEMIC RESEARCH IN BUSINESS AND SOCIAL SCIENCES

Vol. 9, No. 3, March, 2019, E-ISSN: 222 2-6990 @ 2019 HRMARS

about project executions. This will also result to effective project control and evaluation hence better management of resources.

\section{References}

Abdou, Saed M; Yong, Kuan; Othman, Mohammed (2016). "Project Complexity Influence on Project management performance - The Malaysian perspective". MATEC Web of Conferences. 66. doi:10.1051/matecconf/20166600065. ISSN 2261-236X.

Apospori, E., Nikandrou, I., Brewster, C., \& Papalexandris, N. (2008). HRM and Organizational Performance in Northern and Southern Europe, International Journal of Human Resource Management. Vol.19, 7, 1187-1207.

Ballot, Gérard, Fakhfakh, F., \&Taymaz, E. (2006). Who benefits from training and R \& D, the firm or the workers? British Journal of Industrial Relations, Vol.44, 473-495.

Blair, D. \& Sisakhti, R. (2007). "Sales training: what makes it work"? T+D Magazine, August, available at:www.astd.org/astd/Publications/TD_Magazine/2007_pdf/August/0708 ExecSum.htm. Retrieved on 22-2-2014.

Conti, G. (2005). Training, Productivity and Wages in Italy. Labour Economics, Vol.12, 557-576.

Denisi, As and Griffin, R.W (2005). Human Resource Management. New York Houghton Mifflin Coy.https://en.wikipedia.org/wiki/Project management

Development Dimensions International, Inc. DDI (2018). United States and/or other countries. https://www.ddiworld.com/resources/library/white-papers-monographs/nine-bestpractices-of-effective-talent-management

Lewis, J.P. (2000). The project manager's desk reference a comprehensive guide to project planning, scheduling, evaluation, and systems. p.185

Mathis, H. \& Jackson, L. (2004). Human Resource Management, Singapore". Thomson Asia Pte Ltd.

Mesly, O. (2017). Project feasibility - Tools for uncovering points of vulnerability. New York, NY: Taylor and Francis, CRC Press. 546 pages. ISBN 9781498757911.

Peter, N. and Jones, G.E, (2003). PMP certification for dummies. p.63

PMI (2010). A Guide to the Project Management Body of Knowledge p.27-35

Saifalislam, K. M., Osman, A \& AlQudah, M.K (2014) Human Resource Management Practices: Influence of recruitment and selection, and training and development on the organizational performance of the Jordanian Public University School of Business Innovation and Technopreneurship, University Malaysia Perlis (UniMAP). IOSR Journal of Business and Management (IOSR-JBM) Volume 16, Issue 5. Vol 5. (May. 2014), PP 43-46.

Subramaniam, C., Shamsudin, F. M. \& Ibrahim, H. (2011). Linking human resource practices and organizational performance: Evidence from small and medium organizations in Malaysia. Jurnal Pengurusan, 32, 27-37. 